\title{
Advances in Targeting Signal Transduction Pathways.
}

\author{
James A. McCubrey ${ }^{1}$, Linda S. Steelman ${ }^{1}$, William H. Chappell ${ }^{1}$, Lin Sun ${ }^{1,2}$, Nicole M. \\ Davis ${ }^{1}$, Stephen L. Abrams ${ }^{1}$, Richard A. Franklin ${ }^{1}$, Lucio Cocco ${ }^{3}$, Camilla Evangelisti ${ }^{4}$, \\ Francesca Chiarini, Alberto M. Martelli3,4, Massimo Libra ${ }^{5}$, Saverio Candido ${ }^{5}$, \\ Giovanni Ligresti ${ }^{5}$, Grazia Malaponte ${ }^{5}$, Maria C. Mazzarino ${ }^{5}$, Paolo Fagone ${ }^{5}$, Marco \\ Donia $^{5}$, Ferdinando Nicoletti ${ }^{5}$, Jerry Polesel $^{6}$, Renato Talamini ${ }^{6}$, Jörg Bäsecke ${ }^{7}$, \\ Sanja Mijatovic ${ }^{8}$, Danijela Maksimovic-Ivanic ${ }^{8}$, Michele Milella $^{9}$, Agostino Tafuri $^{10}$, \\ Joanna Dulińska-Litewka ${ }^{11}$, Piotr Laidler ${ }^{11}$, Antonio B. D'Assoro ${ }^{12}$, Lyudmyla \\ Drobot $^{13}$, Kazuo Umezawa ${ }^{14}$, Giuseppe Montalto ${ }^{15}$, Melchiorre Cervello ${ }^{16}$, and Zoya \\ N. Demidenko'17. \\ ${ }^{1}$ Department of Microbiology and Immunology, Brody School of Medicine at East Carolina University \\ 2 Department of Communication Sciences and Disorders, College of Allied Health Sciences, East Carolina University, \\ Greenville, North Carolina, USA \\ ${ }^{3}$ Dipartimento di Scienze Biomediche e Neuromotorie, Università di Bologna, Bologna, Italy \\ ${ }^{4}$ Institute of Molecular Genetics, National Research Council-IOR, Bologna, Italy \\ ${ }^{5}$ Department of Bio-Medical Sciences, University of Catania, Catania, Italy \\ ${ }^{6}$ Unit of Epidemiology and Biostatistics, Centro di Riferimento Oncologico, IRCCS, Aviano, Italy. \\ ${ }^{7}$ Department of Medicine, University of Göttingen, Göttingen, Germany \\ 8 Department of Immunology, Instititue for Biological Research "Sinisa Stankovic", University of Belgrade, Belgrade, Serbia \\ ${ }^{9}$ Regina Elena National Cancer Institute, Rome, Italy \\ ${ }^{10}$ Sapienza, University of Rome, Department of Cellular Biotechnology and Hematology, Rome, Italy \\ ${ }^{11}$ Chair of Medical Biochemistry, Jagiellonian University Medical College, Kraków, Poland. \\ 12 Department of Biochemistry and Molecular Biology, Mayo Clinic College of Medicine, Rochester, MN, USA. \\ 13 Palladin Institute of Biochemistry, National Academy of Sciences of Ukraine, Kyiv, Ukraine \\ ${ }^{14}$ Department of Molecular Target Medicine Screening, Aichi Medical University School of Medicine, Nagakute, Aichi, Japan \\ ${ }^{15}$ Biomedical Department of Internal Medicine and Specialties, University of Palermo, Palermo, Italy \\ ${ }^{16}$ Consiglio Nazionale delle Ricerche, Istituto di Biomedicina e Immunologia Molecolare "Alberto Monroy", Palermo, Italy \\ 17 Department of Cell Stress Biology, Roswell Park Cancer Institute, Buffalo, New York, USA \\ Correspondence to: James A. McCubrey, email: mccubreyj@ecu.edu
}

Keywords: Targeted Therapy, Therapy Resistance, Cancer Stem Cells, Raf, Akt, PI3K, mTOR, AMPK, Metformin

Received: December 27, 2012, Accepted: December 28, 2012, Published: December 30, 2012

Copyright: () McCubrey et al. This is an open-access article distributed under the terms of the Creative Commons Attribution License, which permits unrestricted use, distribution, and reproduction in any medium, provided the original author and source are credited.

ABSTRACT:

Over the past few years, significant advances have occurred in both our understanding of the complexity of signal transduction pathways as well as the isolation of specific inhibitors which target key components in those pathways. Furthermore critical information is being accrued regarding how genetic mutations can affect the sensitivity of various types of patients to targeted therapy. Finally, genetic mechanisms responsible for the development of resistance after targeted therapy are being discovered which may allow the creation of alternative therapies to overcome resistance. This review will discuss some of the highlights over the past few years on the roles of key signaling pathways in various diseases, the targeting of signal transduction pathways and the genetic mechanisms governing sensitivity and resistance to targeted therapies. 


\section{Mutations Alter the Activity of the Ras/Raf/MEK/ ERK and PI3K/PTEN/Akt/mTOR pathways.}

The Ras/Raf/MEK/ERK and PI3K/PTEN/Akt/ mTOR pathways are often activated by mutations within individual components of these pathways, as well as the aberrant activation of upstream growth factor receptors. The genetic basis of sensitivity and resistance to various small molecule inhibitors which target these pathways as well a comprehensive list of small molecule inhibitors as a well as their use in clinical trials have recently been published [1-7].

\section{Predicting Sensitivity to Small Molecule Inhibitors.}

Extensive panels of human cell lines have been examined for mutations in genes implicated in cancer as well as for their sensitivity to various inhibitors and chemotherapeutic drugs commonly used to treat cancers $[8,9]$.

The cell lines were intensively interrogated by expression profiling, chromosome copy number, deep sequencing, biostatistical and systems analyses. Both studies indicated that sensitivity to inhibitors was often linked with genetic mutations at key elements in the Ras/Raf/MEK/ERK, PI3K/PTEN/Akt/mTOR and some other pathways. Sensitivity to MEK and Raf inhibitors was often investigated in these studies. Sensitivity to the B-Raf inhibitor PLX4720 was highly associated with particular mutations at $B R A F$ (V600E). Sensitivity to MEK inhibitors was shown to be associated with $B R A F$, NRAS as well as PTEN, PTPN5, SPRY2, DUSP4, DUSP6 mutations and to a lesser extent mutations at $K R A S$. Sensitivity to MEK inhibitors in NRAS mutant lines was linked with aryl hydrocarbon receptor $(A H R)$ expression [9].

Mutation of $B R A F$ or $R A S$ can contribute to the pathogenesis of many cancers, including, melanoma and colo-rectal cancer [10]. BRAF mutations have also been implicated in the pathogenesis of papillary thyroid cancer [11].

Mutation of $B R A F$ and $K R A S$ can result in aberrant c-Myc and SIRT1 protein deacetylase expression in the colorectal cancer [12]. Mutations at $K R A S$ which result in increased mutant Ras activity can interact with increased Wnt expression in lung cancer and lead to a worse prognosis as the tumors arise at an increased incidence and tumors which are also larger [13]. Interesting it was observed that in those tumors where there was increased KRAS and Wnt activities they had a distinct phenotype which was similar to embryonic progenitors found in the developing lung, consistent with the previously described effects of the Wnt pathway on developmental processes.
Novel Targets Interacting with the Ras/Raf/MEK/ ERK Pathway.

Novel upstream Shc regulators such as the multiple copies in T-cell malignancy 1 (MCT-1) gene have been recently described which may become an important therapeutic target as MCT-1 is co-activated with Shc gene in human carcinomas and knockdown of MCT-1 enhances apoptotic cell death [14].

The CDC28 protein kinase regulatory subunit 1B $(C K S 1 B)$ gene is involved in multiple myeloma (MM). There is an inverse correlation between CKS1B expression and survival and it may be a novel therapeutic target [15]. Recently it was shown that CKS1B activates both the Raf/MEK/ERK and STAT3 pathways and promotes drug resistance [16]. Targeting CKS1B may be a novel approach to treat certain cancers.

\section{Advances in Our Understanding and Targeting of the Ras/Raf/MEK/ERK and PI3K/PTEN/mTOR Pathways.}

Effective inhibitors specific for many of the key components of the Ras/Raf/MEK/ERK/MNK, Ras/PI3K/ PTEN/mTOR and other pathways have been developed. These pathways are often implicated in therapeutic resistance and interact with many pathways. [17-23].

Ras inhibitors have been examined in many studies including clinical trials. However the results so far have not been encouraging. Salirasib (Farnesythiosalycilic acid, FTS) is a Ras inhibitor. It has recently been demonstrated that FTS treatment of immuno-competent mice with subcutaneous or intracranial brain tumors resulted in a favorable antitumor environment [24]. The authors observed an increase in regulatory T-cells which altered the tumor microenviroment and preventing the resistance of the tumor cells to destruction by the immune system.

BRAF inhibitors have been shown to be effective in the treatment of melanomas. One of the first described Raf inhibitors, Sorafenib, has been shown to inhibit many targets, including VEGFR, PDGFR and Raf. It is approved for treatment of hepatocellular carcinoma (HCC) where there are few effective therapeutic approaches [25]. The mechanism of actions of sorafenib have been further elucidated and it has been determined to alter the expression of many genes in HCC [26]. A recent genomic analysis indicated that sorafenib significantly altered expression levels of 826 and 2011 transcripts in HepG2 and Huh7 cells, respectively. The affected genes whose expression were upregulated in response to sorafenib treatment were determined to be involved in angiogenesis, apoptosis, transcription regulation, signal transduction, protein biosynthesis and modification, In contrast, genes which were determined to be downregulated after sorafenib treatment were involved in cell cycle control, 
DNA replication recombination and repair, cell adhesion, metabolism and transport. Each sorafenib-treated HCC cell line displayed specificity in the expression and activity of crucial factors involved in hepatocarcinogenesis.

The p21-activated protein kinase 1 (PAK1) kinase also interacts with the Ras/Raf/MEK/ERK and the PI3K/ PTEN/Akt/mTOR cascades. PAK signaling molecules are downstream effectors of Rho family GTPase and interact with both Raf and Akt. PAK inhibitors have been developed [27]. Interestingly, IPA3 inhibits the proliferation of melanoma and colorectal cancer cells with mutations at $K R A S$ or $N R A S$ better, than those containing mutations at $B R A F$. Treatment of cells with IPA3 or ectopic expression of DN PAK1 sensitized cell with $R A S$ mutations to the B-Raf inhibitor GDC-0897 or the MEK inhibitor ZD6244.

Neurofibromin is a GTP-ase activating protein (GAP) which is mutated in neurofibromatosis patients and is considered a tumor suppressor. Neurofibromin normally can regulate cell motility often via the Ras/Raf/MEK/ERK cascade by an interaction of the Ras GTPase-activating protein-related domain (GRD) present on Neurofibromin. Neurofibromin can also regulate Rho-dependent (Rasindependent) event by activating LIM kinase 2 (LIMK2). LIMK2 can phosphorylates and inactivates cofilin (a key protein involved in actin-depolymerization factor). Finally, the pre-GRD domain present on Neurofibromin can interact with Rac1 GTPase, which activate the P21 activated kinase 1 (PAK1)-LIMK1-cofilin pathway. T56-LIMKi is a novel inhibitor that was isolated by molecular modeling that suppressed LIMK1/2 kinase activities which blocked the phosphorylation of cofilin and disrupted actin structure and prevented effects associated with tumorigenicity. The combined effect of the Ras inhibitor Salirasib and T56-LIMKi on cell proliferation were examined and synergistic effects were observed [28].

The PIM kinases can also interact with the EGFR/ Ras/Raf/MEK/ERK pathway and certain PIM kinase inhibitors will induce the MIG6 gene which encodes a suppressor of EGFR signaling. These PIM specific inhibitors (M-110 and SGI-1776) suppress ERK activation in prostate cancer cells. Moreover synergistic effects were observed when the PIM inhibitors were combined with the EGFR inhibitor Gefitinib. These results indicate that the efficacy of EGFR inhibitors may be improved by PIM inhibitors [29].

Ras and other transformed cells often become addicted to autophagy. Targeting certain Ras-addicted cells with autophagy inhibitors (chloroquine and the derivative hydroxychloroquine) may prove to be an effective therapeutic approach [30].

\section{Rationale for Targeting Multiple Points in Ras/ Raf/MEK ERK Pathway or Multiple Pathways.}

An emerging concept in cancer therapy is the targeting of multiple points in a single signaling pathway. It has been proposed that targeting of both Raf and MEK or Raf and ERK may be useful in certain cancer therapies [31]. The concept of targeting both Raf and MEK is especially true with BRAF inhibitors and melanoma which contain mutations at BRAFV600E due to the negative feedback elicited by downstream ERK which suppresses the sensitivity of the cells to signaling induced by growth factors and Ras activity is low [32]. In these cells the mutant BRAF protein functions as a monomer. The Raf inhibitors suppress the activity of the BRAF monomers but not dimers. Inhibiting the BRAFV600E protein by the BRAF inhibitors inhibits the BRAFV600E protein which suppresses the normal negative ERK-mediated feedback of this pathway. However, this results in reactivation of ligand-dependent signal transduction and increased Ras activity and induces generation of Raf-inhibitor resistant Raf dimers and activation of MEK and downstream ERK. Thus combined Raf and MEK inhibitor treatment may become effective anti-cancer approach. Targeting both MEK and mTOR is a method to target melanoma which often have mutations at $B R A F$ and increased activation of the PI3K/PTEN/Akt/mTORC1 pathway [33]. The Ras/ Raf/MEK/ERK and PI3K/PTEN/Akt/mTORC1 pathways are regulated by extensive crosstalk, occurring at different levels. In cancer, transactivation of the alternate pathway is a frequent "escape" mechanism. Thus combined inhibition of both pathways may achieve synergistic antitumor activity. In the M14 melanoma model, simultaneous inhibition of both MEK and mTORC1 achieved synergistic effects at suboptimal concentrations.

\section{Advances in Targeting Anti-Apoptotic Molecules which are Regulated by Ras/Raf/MEK/ERK and PI3K/PTEN/Akt/mTOR Pathways.}

The effects of combining MEK and Bcl-2 inhibitors on AML cells has been investigated [34]. Anti-apoptotic proteins such as $\mathrm{Bcl}-2, \mathrm{Bcl}-\mathrm{X}_{\mathrm{L}}$ and $\mathrm{Mcl}-1$ are key therapeutic targets in human cancer. The mechanisms of actions the Bcl-2 inhibitor ABT-737 have been further elucidated [35]. This Bcl-2 inhibitor suppresses Bcl-2 and Bcl- $\mathrm{X}_{\mathrm{L}}$ but not Mcl-1. ABT-737 treatment results in activation of the Raf/MEK/ERK cascade and downstream Mcl-1 in AML cells. The MEK inhibitor PD0325901 suppresses Mcl-1 expression. Combining PD0325901 with ABT-737 resulted in synergistic killing of AML-derived cell lines, primary AML blasts and the $\mathrm{CD} 34^{+}, \mathrm{CD} 38^{-}$ , $\mathrm{CD} 123^{+}$population which is enriched in progenitor/ stem cells. These studies suggest a novel and effective therapeutic strategy for patients with AML. 
Treatment of AML cells with ABT-737 and PI3K/ mTOR inhibitors (BEZ235 or PI-103) resulted in a synergistic response in AML cells, but importantly not in normal $\mathrm{CD}^{+} 4^{+}$cells [36]. This synergy was shown to result from inhibition of Bcl-2 and $\mathrm{Bcl}-\mathrm{X}_{\mathrm{L}}$ and the effects of $\mathrm{PI} 3 \mathrm{~K} / \mathrm{mTOR}$ inhibitors were shown to be GSK-3 and Bim dependent. The PI3K/mTOR inhibitors downregulated Mcl-1 but increased Bim binding to Bcl2/Bcl-XL. Knock-down of GSK-3alpha/beta prevented Mcl-1 downregulation and decreased apoptosis induced by PI3K/mTOR inhibitors. Combining PI3K/Akt/mTOR inhibitors with $\mathrm{BH} 3$-mimetics may be an approach to treat AML especially in those patients who exhibit Akt activation [37].

\section{Advances in Targeting Cancer Initiating Cells.}

The Ras/Raf/MEK/ERK, PI3K/PTEN/Akt/ mTOR, Wnt/beta-catenin, Notch, Hedgehog and other pathways are being shown to play key roles in cancer initiating cells (CICs) and leukemia initiating cells (LIC). Deregulated expression of oncogenes such as Raf-1 have been associated with drug resistance, epithelial to mesenchymal transition and CIC survival [38]. Following metastatic dissemination, cancer cells often re-activate certain epithelial properties through mesenchymal to epithelial transition (MET) to establish neoplastic lesions at secondary sites. The molecular mechanisms regulating MET remain elusive. Recently MET has been examined in estrogen-receptor alpha positive (ERalpha+) MCF-7 breast cancer cells which overexpress activated Raf- 1 and are more resistant to the chemotherapeutic drug doxorubicin than parental MCF-7 cells. Constitutive expression of activated Raf-1 induced HER-2/Neu overexpression and lead to distant metastases in xenografts. The development of distant metastases in xenograft models was linked to activation of the MET pathway as the cells expressed reduced expression of EMT inducer genes (TGFB2, TWIST1 and FOXC1) and overexpression of BMB7, $C X C R 7$ and early growth response (EGR) family of transcription factors.

The mitotic kinase Aurora-A promotes metastases by inducing EMT transition in ERalpha+ MCF-7 breast cancer cells which expressed constitutively-active Raf1 [39]. Constitutive expression of activated Raf-1 in MCF-7 cells induced stabilization and accumulation of Aurora-A mitotic kinase. This drove the transition from an epithelial to a highly invasive mesenchymal phenotype. This transition resulted in reduced expression of ERalpha, HER-2/Neu over-expression, and loss of CD24 surface receptor (CD24-/low). Importantly, expression of key EMT markers and upregulation of the stemness gene SOX2 was linked to acquisition of stem cell-like properties. The cells had an increased ability to form mammospheres in vitro and tumor self-renewal in vivo. Moreover, the aberrant Aurora-A kinase activity induced phosphorylation and nuclear translocation of SMAD5, suggesting a novel interplay between Aurora-A and SMAD5 signaling pathways which may be important in the development of EMT, stemness and ultimately tumor progression. Pharmacologic or molecular inhibition of Aurora-A kinase activity restored a CD24 $4^{+}$epithelial phenotype. This phenotype was associated with restored ERalpha expression, down-regulation of HER-2/Neu, inhibition of EMT and impaired self-renewal ability and suppression of metastases. Thus mitotic kinase Aurora-A is a promising therapeutic target to selectively eliminate highly invasive cancer cells.

\section{Advances in Elucidation of Roles of the PI3K/ PTEN/Akt/mTOR Pathway in Oncogenesis.}

The PI3K pathway has recently been shown to be important in c-Myc expression in Burkitt's lymphomagenesis in germinal center B cells [40]. The $\mathrm{PI} 3 \mathrm{~K}$ pathway is also an emerging target for mantle cell lymphoma as this cascade is upregulated in this cancer [41]. Disruption of PTEN and p53 activity specifically in the thyroid has recently been shown to result in murine models of anaplastic thyroid carcinomas [42]. These models could be important for the development of approaches to target human thyroid carcinomas. The PI3K pathway is important in many cancer including gliomas often due to aberrant PTEN expression. Recently it was show that reduction of $P I K 3 C A$ or $P I K 3 R A$ expression impeded proliferation, migration, and invasion in glioblastoma multiforme cells [43]. In contrast to PI3Kalpha, PI3K-beta is oncogenic in its WT configuration if it is overexpressed. PI3K-beta acts like an oncogenic mutant of PI3K-alpha [44]. PI3K-delta has been shown to have roles in BCR-ABL-mediated chronic lymphocytic leukemia (CLL) by suppressing BCR signaling [45]. Elevated PI3K signaling has been detected in certain breast cancer subtypes and is believed to drive their abnormal proliferation [46]. Novel lipid phosphatases have been shown to be important in regulation of this pathway. Inositol polyphosphate 4-phosphatase type II (INPP4B), is tumor suppressor in implicated in many cancers such as prostate, breast, and ovarian cancers and also potentially in leukemia [47]. Akt has recently been shown to be an important molecule in regulation of homologous recombination and genetic stability in hereditary and sporadic breast cancers [48].

\section{Advances in Targeting the PI3K/PTEN/Akt/ mTOR Pathway.}

The PI3K/PTEN/Akt/mTOR pathway is also involved in drug resistance, sensitivity to therapy and metastasis [49-58]. PIK3CA mutations may act as driver mutations in certain cancers responsible for metastasis 
[59]. Novel PI3K-alpha inhibitors have been isolated and they inhibit metastasis [60]. Most PI3K inhibitors are cytostatic rather than cytotoxic and it has been questioned whether treatment with a single PI3K inhibitor will be effective [61].

There have been many recent advances in the development of inhibitors which target this pathway. One of the key developments is in dual PI3K/mTOR inhibitors. Waldenstrom's macroglobulinemia proliferates, in part, in response to aberrant PI3K/Akt activity. The dual PI3K/ Akt inhibitor NVP-BEZ235 suppresses the growth of the Waldenstrom's anemia cells as well as has effects on the tumor microenvironment [62].

The PI3K/Akt/mTOR signaling network is activated in acute leukemias of both myelogenous and lymphoid lineage, where it correlates with poor prognosis and enhanced drug-resistance. Treatment of AML and ALL with dual PI3K/mTOR inhibitors has been shown to be more effective than treatment with rapamycin which blocks mTORC1 but not mTORC2 [63]. The dual PI3K/ mTOR inhibitors suppressed the rapamycin-resistant phosphorylation of eukaryotic initiation factor 4E-binding protein 1. The novel dual PI3K/mTOR inhibitor NVPBEZ235, an orally bioavailable imidazoquinoline derivative, has entered clinical trials. Moreover in both T-ALL cell lines and patient samples. NVPBEZ235 was cytotoxic to a panel of T-ALL cell lines as determined by MTT assays. NVP-BEZ235 induced cell cycle arrest and apoptosis. A dose- and time-dependent dephosphorylation of Akt and mTORC1 downstream targets was observed after NVP-BEZ235 treatment. NVP-BEZ235 targeted the side population of both T-ALL cell lines and patient lymphoblasts, which is enriched in leukemia initiating cells (LIC), and synergized with chemotherapeutic agents (cyclophosphamide, cytarabine, dexamethasone) which are used currently for treating T-ALL patients. NVP-BEZ235 reduced chemoresistance to vincristine induced in Jurkat $\mathrm{T}$ cells upon coculturing with MS-5 stromal cells, which mimics the bone marrow microenvironment. NVP-BEZ235 was cytotoxic to T-ALL patient lymphoblasts displaying pathway activation, where the drug dephosphorylated eukaryotic initiation factor 4E-binding protein 1, in contrast rapamycin did not elicit such changes. Longitudinal inhibition at two nodes of the PI3K/Akt/mTOR network with NVP-BEZ235, either alone or in combination with chemotherapeutic drugs, may be an efficient treatment of those T-ALLs that have aberrant upregulation of this signaling pathway for their proliferation and survival [64].

The dual PI3K/mTOR inhibitor NVP-BEZ235 has also been shown recently to synergize with a panhistone deacetylase inhibitor in suppressing the growth of pancreatic cancer [65].

Effective Akt inhibitors have been recently developed. The Akt inhibitor MK-2206 has been shown to be effective in suppressing the growth of many cancers including leukemias. This Akt inhibitor is currently in many clinical trials with cancer patients have diverse diseases either as a single or combined agent with an additional signal transduction inhibitor or chemo- or endocrine therapy [65]. The PI3K/PTEN/Akt/mTORC1 pathway is frequently upregulated in T-ALL, The effects of the novel allosteric Akt inhibitor, MK-2206, on a panel of human T-ALL cell lines and primary cells from T-ALL patients were examined. MK-2206 decreased cell viability by blocking leukemic cells in $\mathrm{G}_{0} / \mathrm{G}_{1}$ and induced apoptosis as well as autophagy and a concentration-dependent dephosphorylation of Akt and its downstream targets, GSK-3alpha/beta and FOXO3A. MK-2206 was cytotoxic to primary T-ALL cells and importantly induced apoptosis in the T-ALL patient cell subset (CD34+, CD4-, CD7'), which are enriched in LICs. Akt inhibition may represent a potential therapeutic strategy in T-ALL.

Alkylphospholipids and alkylphosphocholines (APCs) are promising antitumor agents, which target the plasma membrane and affect multiple signal transduction networks including Akt. The therapeutic potential of erucylphosphohomocholine (ErPC3), the first intravenously applicable APC, on human AML cells was determined. At short (6-12 h) incubation times, ErPC3 blocked cells in $\mathrm{G}_{2} / \mathrm{M}$ phase of the cell cycle, whereas, at longer incubation times, it decreased survival and induced apoptotic cell death. ErPC3 induced JNK 1/2 activation while stimulating ERK $1 / 2$ dephosphorylation. Pharmacological inhibition of caspase-3 or a JNK 1/2 inhibitor peptide reduced ErPC3 cytotoxicity. Protein phosphatase $2 \mathrm{~A}$ downregulation by siRNA inhibited ERK $1 / 2$ dephosphorylation and blunted the cytotoxic effects of ErPC3. ErPC3 was also cytotoxic to AML primary cells and importantly reduced the clonogenic activity of $\mathrm{CD} 34^{+}$ leukemic cells. ErPC3 treatment induced apoptosis in the $\left(\mathrm{CD} 34^{+}, \mathrm{CD} 38(\mathrm{Low} /-), \mathrm{CD} 123^{+}\right)$compartment which is enriched in putative LICs. ErPC3 induced cytotoxicity on AML blasts which expressed high levels of aldehyde dehydrogenase activity and on the side population of AML cell lines and blasts in which the LIC populations are believed to reside. Thus ErPC3 might be a promising therapeutic agent for the treatment of AML patients [66].

\section{Advances in Understanding the Pleiotropic Effects of mTOR.}

The importance of mTOR and its inhibition in various conditions, including cancer, diabetes, aging and others has been further elucidated. Recently mTOR has been shown to be cell cycle regulated $[67,68]$. mTOR has been referred to as the gatekeeper of autophagy. mTOR plays important roles in many biological processes, including; autophagy [69] energy control [70-72], insulin resistance [73], diabetes [74,75], seizures [76,77], protein homeostasis [78], regulation of tRNA expression 
$[79,80]$, cell cycle arrest [81], cell differentiation [82,83], cell migration [84,85], follicle development [86], DNA damage checkpoint [87], DNA replication stress [88],cellular quiescence/senescence [89-107] progeria [108], age-related retinal diseases [109], obesity [110], stem cells [111], cancer [112,113], aging [114-134], Alzheimer's disease [135] and Parkinson's disease [136]. mTORC1 is a critical repressor of autophagy, a lysosome-dependent degradation pathway which allows cells to recycle damaged or unnecessary cytoplasmic content, such as lipids, proteins, and organelles [138-156]. As a consequence, cells produce metabolic precursors for macromolecular biosynthesis or ATP generation. In cancer cells, autophagy fulfills a dual role, as it has both tumorpromoting and tumor-suppressing properties. Functional autophagy prevents necrosis and inflammation, which can lead to genetic instability. However, autophagy is important for tumor progression by providing energy through its recycling mechanism during unfavorable metabolic circumstances, which frequently occurs in certain tumors [138-156].

A model was proposed recently by Dr. Michael P. Lisanti and colleagues which is called the reverse Warburg Effect. This model proposes that the aerobic glycolysis occurring in the tumor associated fibroblasts and not in the actual epithelial tumor cells [142,146-150]. This results in the transfer of high-energy metabolites (lactate and pyruvate) to adjacent epithelial cancer cells which fuel the cancer cells allowing them to invade and metastasize. In addition, oxidative stress generated by the cancer cells induces autophagy of the tumor associated fibroblasts which the cancer cells then recycle and use to fuel their growth. Anti-oxidants ( $\mathrm{N}$-acetyl cysteine, $\mathrm{NAC}$ ), quercetin and the anti-diabetes drug metformin) or autophagy inhibitors (chloroquine) will suppress the destruction of caveolin-1 in stromal fibroblasts and inhibit cancer growth. Caveolin-1 is a key protein at the cell membrane which serves to organize other important signaling molecules into signaling complexes (e.g., Fak, $\mathrm{Src})$. Decreased expression of caveolin-1 is associated with a poorer prognosis of breast and other cancers.

Autophagy is also important in blood cancers [151-153]. Autophagy can be regulated by epigenetic mechanisms [154]. Autophagy may also become defective in certain drug resistant cells [155]. Defective autophagy may be controlled by the p53 rheostat in cancer [156]. Clearly autophagy is a very important survival process which is regulated in part by mTORC1.

The mTORC1 blocker rapamycin may be useful in the treatment of many diseases including HIV and HCV infections $[157,158]$.

\section{Advances in mTOR Kinase Inhibitors.}

mTOR kinase inhibitors have been developed and evaluated on many diseases including leukemias [159].
mTOR is present in two complexes, mTORC1 and mTORC2. Both of these complexes play critical roles in signal transduction pathways and regulate cell growth and many other physiological processes. Rapamycin and rapalogs only inhibit (block) mTORC1. Allosteric inhibition of mTORC1 by rapamycin had only modest effects in T-ALL. ATP-competitive inhibitors specific for the mTOR kinase active site have been developed recently. The therapeutic potential of active-site mTOR inhibitors in suppressing growth in T-ALL cell lines and primary samples from T-ALL patients which had activation of mTORC1 and mTORC2 was examined. The inhibitors affected T-ALL cell viability by inducing $\mathrm{G}_{0} / \mathrm{G}_{1}$ cell cycle arrest, apoptosis and autophagy. Decreased levels of the mTORC2 target Ser 473 Akt were detected as well as dephosphorylation of mTORC1 downstream targets. Unlike rapamycin, marked inhibition of mRNA translation in T-ALL cell lines treated was observed with active-site mTOR inhibitors. The mTOR inhibitors synergized with both vincristine and the Bcl-2 inhibitor, ABT-263. The mTOR inhibitors targeted a putative LIC sub-population $\left(\mathrm{CD} 34^{+}, \mathrm{CD} 7^{-}, \mathrm{CD} 4^{-}\right)$in the ALL patient samples. The mTOR inhibitors displayed remarkable anti-leukemic activity, and could become clinical candidates for T-ALL therapy [160].

\section{Advances in Targeting the NF-kappaB Pathway.}

Targeting the NF-kappaB pathway has been shown to be a potential therapeutic approach in leukemia and other therapies. The NF-kappaB pathway is regulated in part by PI3K/PTEN/Akt/mTOR pathway. The IkappaB kinase (IKK)/NF-kappaB axis is required for viability of leukemic cells and is a predictor of relapse in T-ALL. It turns out that many anticancer agents induce NF-kappaB nuclear translocation. This results in activation of NFkappaB target genes, which can alter the sensitivity to chemotherapeutic drugs. The I-kappaB kinase inhibitor is the target of BMS-345541 [161]. The anti-proliferative effects of BMS-345541 in three Notch1-mutated T-ALL cell lines and in T-ALL primary cells from pediatric patients were investigated. BMS-345541 induced apoptosis and accumulation of cells in the $\mathrm{G}_{2} / \mathrm{M}$ phase of the cell cycle. T-ALL cells treated with BMS-345541 displayed nuclear translocation of FOXO3a as well as downstream $\mathrm{p} 21^{\mathrm{Cip} 1}$ expression. FOXO3a subcellular re-distribution was independent of AKT and ERK 1/2 signaling, suggesting that in T-ALL, the loss of FOXO3a tumor suppressor function could be due to deregulation of IKK. FOXO3a mutations are not frequently found in human tumors. Thus therapeutics activating FOXO3a may be more effective than others. BMS-345541 could be used alone or in combination with traditional therapies in the treatment of T-ALL.

Dehydroxymethyl-epoxyquinomicin (DHMEQ) is an inhibitor of NF-kappaB [162] DHMEQ induces 
apoptosis through reactive oxygen species (ROS) production in hepatoma cells. Cox-2 inhibition is an additional approach to inhibit hepatoma cell growth [163]. Celecoxib can also synergize with the proteasome inhibitor MG132 and suppress the growth of hepatocellular carcinoma [164]. Subsequently DHMEQ was determined to synergize with the Cox-2 inhibitor celecoxib in hepatoma cells, again via a ROS-dependent mechanism [165]. DHMEQ cooperated with celecoxib (CLX) to decrease NF-kappaB DNA binding and inhibited cell proliferation more effectively than treatment with these single agents alone. DHMEQ-CLX combination resulted in ROS production which in turn induced the expression of genes involved in endoplasmic reticulum (ER) stress. Silencing TRB3 mRNA, which is associated with ER stress, significantly decreased DHMEQ-CLX-induced cell growth inhibition. The DHMEQ-CLX combined treatment was associated with induction of PARP cleavage and down-regulation of the anti-apoptotic proteins Bcl-2, Mcl-1 and survivin, as well as activated Akt. CD95 and CD95 ligand expression increased synergistically in the combined treatment, which was reversed in the presence of NAC. Knockdown of CD95 mRNA expression decreased DHMEQ-CLX-induced growth inhibition in HCC cell lines. Thus the DHMEQ-CLX combination killed hepatoma cells via ROS production, ER stress response and the activation of intrinsic and extrinsic apoptotic pathways.

\section{Advances in Targeting Multiple Points in PI3K/ PTEN/Akt/mTOR pathway.}

An emerging concept in cancer therapy is the targeting of multiple points in the PI3K/PTEN/Akt/mTOR and other pathways. The expression of the PI3K/PTEN/ $\mathrm{Akt} / \mathrm{mTOR}$ pathway is often upregulated in melanomas. The dual PI3K/mTOR inhibitor NVP-BEZ235 inhibited melanoma growth regardless of $B R A F$ mutation status. Rapamycin enhanced the activity of the dual PI3K/ mTOR inhibitor NVP-BEZ235 in inhibiting the growth of melanoma [166]. Furthermore addition of the MEK inhibitor AZD6244 synergized with the dual PI3K/mTOR inhibitor NVP-BEZ235 in suppressing melanoma growth.

The effects of targeting different levels of the PI3K/ PTEN/Akt/mTOR pathway has also been examined in various leukemias [167]. The efficacy of co-targeting of different components of the PI3K/PTEN/Akt/mTOR pathway with a novel dual PI3K/Akt inhibitor has been investigated in T-ALL. [168]. The dual PI3K/PDK1 inhibitor NVP-BAG956 was determined in one study to exert the most powerful cytotoxic affects against T-ALL cell lines and primary patients samples, in comparison to a pan class I PI3K inhibitor (GDC-0941), an allosteric Akt inhibitor (MK-2206), an mTORC1 allosteric inhibitor (RAD-001), or an ATP-competitive mTORC1/mTORC2 inhibitor (KU63794).

Often signal transduction inhibitors are cytostatic as opposed to cytotoxic. This is especially true with rapamycin. The effects of combining targeted therapy with chemotherapy is an emerging concept and is also being examined by clinical trials [169]. The therapeutic potential of a combination of temsirolimus [an allosteric mTOR complex 1 (mTORC1) inhibitor] with clofarabine, a nucleoside analogue with potent inhibitory effects on both ribonucleotide reductase and DNA polymerase was examined in AML cell lines and clinical specimens. The drug combination (CLO-TOR) displayed synergistic cytotoxic effects against a panel of AML cell lines and in primary cells from AML patients. The CLO-TOR treatment induced arrest at the G0/G1 phase of the cell cycle, apoptosis, and autophagy. CLO-TOR combination was pro-apoptotic in an AML patient blast subset $\left(\mathrm{CD} 34^{+}\right.$, CD38, CD123 $^{+}$), which is enriched in putative LICs. The CLO-TOR combination could represent a novel valuable treatment for AML patients, also in light of its efficacy against LICs.

\section{Activation of Liver Kinase B1/AMP Activated Protein Kinase Pathway as an Anti-Cancer Therapy.}

The liver kinase B1/AMP activated protein kinase (LMPK) pathway has been determined to be a key pathway in metabolism (diabetes) as well as cancer and other diseases [170]. The LKB1/AMPK network remains functional in a wide range of cancers and can be stimulated by drugs, such as N,N-dimethylimidodicarbonimidic diamide (metformin) or 5-aminoimidazole-4-carboxamide $1-\beta$-D-ribofuranoside (AICAR). LKB1/AMPK signaling induces cell cycle arrest, caspase-dependent apoptosis or autophagy in various tumors. Metformin inhibits mTORC1-controlled oncogenetic protein translation, which does not occur with allosteric mTORC1 inhibitors, such as rapamycin and its derivatives. Metformin also targets LICs and CICs, the critical target for leukemia eradication. Thus the LKB1/AMPK pathway is critically involved in regulating proliferation and survival of malignant cells. Drugs activating LKB1/AMPK may be both a novel and less toxic treatment option for certain malignancies [171-174].

The effects of metformin against T-ALL cell lines and primary samples from T-ALL patients displaying mTORC1 activation. Metformin inhibited T-ALL cell viability by inducing autophagy and apoptosis. Importantly, it was much less toxic against proliferating $\mathrm{CD}^{+} \mathrm{T}$-lymphocytes from healthy donors. Dephosphorylation of downstream targets of mTORC1 were detected. A marked inhibition of mRNA translation in T-ALL cells treated with metformin, in contrast such an inhibition of translation was not observed after rapamycin 
treated. Remarkably, metformin targeted the side population of T-ALL cell lines as well as a putative LIC subpopulation $\left(\mathrm{CD}^{-} 4^{+}, \mathrm{CD}^{-}, \mathrm{CD}^{-}\right)$in primary patient samples. Metformin displayed a remarkable anti-leukemic activity, which emphasizes future development of LKB1/ AMPK activators as clinical candidates for therapy of T-ALL [175]. AMPK has also been shown to be important in BCR-ABL-induced CML and AMPK activators may prove useful as supplemental drugs for this disease [176]. AMPK can also be activated by rapamycin [177].

The plant natural product berberine has recently been shown to inhibit the growth of drug resistant breast cancer cells whereas the parental drug sensitive line was not as growth inhibited [178]. Berberine may also target LKB1/AMPK. Breast cancer cells overexpressing neutrophil gelatinase associated lipocalin (NGAL) were more sensitive to berberine than parental cells which did not over express NGAL [178].

\section{Advances in Understanding the p53 Pathway and Targeting.}

Both the PI3K/PTEN/Akt/mTOR and Ras/Raf/ MEK/ERK pathways can interact with the p53 pathway at various levels. Functional p53 gene status was determined to be important in the sensitivity of prostate cancer cells to chemotherapeutic drugs, radiation treatment and the small molecule MDM2 inhibitor Nutlin 3A. [179]. The p53 transcription factor is a critical element in the ability of the cell to regulate the cell cycle and its response to DNA damage. Mutations within the DNA-binding domain of p53 are common in human cancers and allow the formation of tetramers; however, these alterations prevent this protein complex from associating with appropriate target gene promoters. The effects of p53 functionality in prostate cancer cells that harbored WT or mutant forms of the protein in response to commonly used chemotherapeutic drugs were examined. The androgen receptor positive $22 \mathrm{Rv}-1$ and $\mathrm{LNCaP}$ prostate cancer cell lines carry WT p53 and were demonstrated to have a decrease in chemotherapeutic drug sensitivity when transfected with a dominant-negative (DN) p53 gene. Conversely, expression of a WT p53 gene in the p53-mutated and more advanced DU145 prostate cancer cell line significantly increased its overall sensitivity to anti-neoplastic drugs. Analysis of colony formation in soft agar revealed that the functional status of p53 in each cell line altered the ability to proliferate in an anchorageindependent fashion. Prostate cancer colony growth was more prevalent when p53 transcriptional activity was decreased, whereas growth was more limited in the presence of functional p53. Thus the functional status of the tumor suppressor p53 is important in the progression of prostate cancer and dictates the overall effectiveness a given drug would have on disease treatment. p53 has also been shown to be a target for lowering associated toxicity of normal cells after chemotherapy. The protection of normal cells from cell cycle-specific chemotherapeutic agents such as mitotic inhibitors (MI) was examined after a 3-day exposure to MI (paclitaxel and nocodazole) by colony formation. In three normal human cell types with WT-p53 (RPE, NKE, WI-38t cells) but not in cancer cells with mutant $\mathrm{p} 53$, pre-treatment with Nutlin-3a, caused G1 and/or G2 arrest, thus preventing lethal mitotic arrest normally induced by MIs and allowing normal cells to recover after removal of the MIs. Rapamycin potentiated the protective effects of Nutlin-3a in the p53-WT cells. Also, a combination of rapamycin and metformin, induced $\mathrm{G}_{1}$ and $\mathrm{G}_{2}$ arrest selectively in p53-WT cells and thereby protected them from the MIs. A combination of metformin and rapamycin also protected p53-WT cells in low glucose conditions, whereas it was cytotoxic for p53 mutant cells. A rational combination of metformin and rapamycin may potentiate chemotherapy with MIs, while protecting normal cells thus therapyinduced toxicities [180-181].

\section{Advances in Roles of Androgen Receptor, Beta- Catenin, and Akt in Androgen Responsiveness of Prostate Cancer.}

The effects of silencing androgen receptor (AR), beta-catenin and Akt expression in prostate cancer growth and migration were examined [182]. The mechanisms responsible for the conversion of prostate cancer from androgen-sensitive (AS) to androgen-insensitive (AI) are not well understood. AR signaling involves cross-talk with the other signaling pathways, and other proteins, such as beta-catenin. To further elucidate some of the biochemical changes that occur during the switch from AS to AI form, AR, Akt and $\beta$-catenin expression were knocked-down with respective siRNAs. Treatment of AR+ LNCaP prostate cells with siRNA for AR significantly reduced proliferation (45-70\%), expression of nuclear $\beta$-catenin, cyclin-D1, cyclin-G1, c-Myc as well as activity of metalloproteinases (MMPs) -2,-7,-9 and cell migration. After longer periods of AR silencing (over 72 hrs) in LNCaP cells, elevated levels of activated Akt were detected and enhanced proliferation as well as expression of nuclear beta-catenin, cyclin-D1, c-Myc and activity of MMPs were observed. Such effects were not observed in either AI, AR-, PC-3 or DU145 cells. However, silencing of Akt and /or beta-catenin in those as well as in AS, AR+ LNCaP cells led to decreased proliferation and migration. These studies indicate that either AR or Akt signaling prevails, depending on their initial androgen sensitivity as well as its availability. In AI prostate cancer cells, Akt takes over the role of AR and more effectively contributes through the same signaling molecule, beta-catenin, to AI cancer progression. Thus Akt can be a key target in 
prostate cancer.

\section{Advances in NO-Modified Drugs and Inhibitors.}

Recently the effect on nitric oxide (NO)-modified inhibitors and drugs has been examined in various cancer settings [183-185]. The NO-modified form of HIV protease inhibitor Saquinavir (Saq) is a potent antitumoral agent efficient against numerous tumor cell lines in vitro and in vivo. Saq-NO was determined to sensitize certain types of cells to tumor necrosis factorrelated apoptosis-inducing ligand (TRAIL)-mediated cell death. Saq-NO inhibited both the growth of $\mathrm{LNCaP}$ cells in vitro and in xenograft models. Suppression of tumor growth was accompanied with cell cycle arrest in $\mathrm{G}_{0} / \mathrm{G}_{1}$ phase. Permanent abrogation of S6 phosphorylation was observed. Diminished S6 phosphorylation was associated with re-established sensitivity to TRAIL and reduction of X-linked inhibitor of apoptosis protein (XIAP). NO modification of Saq led to a new chemical entity with stronger and more pleiotropic antitumor activity than the parental drug.

The effects of the NO-modified anti-inflammatory drug (S,R)-3-phenyl-4,5-dihydro-5-isoxasole acetic acid (VGX-1027) named GIT-27NO or the NO-modified antiviral drug saquinavir (Saq) named Saq-NO were examined on colon cancer cell lines, murine CT26CL25 and human HCT116. Both agents suppressed the growth of colon cancer cells in vitro. The efficacy of the drugs was evaluated in vivo in BALB/c mice injected with CT26CL25 cells. Both agents suppressed reduced tumor volume in syngeneic BALB/c mice. However, their mechanisms of action were different as GIT-27NO released larger amounts of nitrite than Saq-NO in vitro and its antitumor action depended on the intracellular NO release. In contrast, Saq-NO released barely detectable amounts of $\mathrm{NO}$ and its antitumor action was NO-independent. Cotreatment with an NO-peroxynitrite scavenger revealed that GIT-27NO but not Saq-NO acts through peroxynitrite-mediated cell destruction. GIT-27NO predominately induced proapoptotic signals followed by caspase-dependent apoptosis. While SaqNO blocked cell proliferation, changed their adhesive, migratory, and invasive properties, and decreased their metastatic potential in vivo. In conclusion, differences in NO release and oxidative stress generation between GIT$27 \mathrm{NO}$ and Saq-NO resulted in different mechanisms that resulted in cell death [186].

\section{Advances in Elucidating Role of NGAL in Cancer.}

Neutrophil gelatinase associated lipocalin (NGAL aka lipocalin-2 or siderocalin) has been shown to play diverse roles, from stabilizing matrix matalloproteinase (MMP-9) to combating bacterial infection by binding bacterial siderophores and preventing bacterial iron sequestration to roles in cancer invasion, EMT, and metastasis [187]. NGAL is believed to play roles in promoting survival, growth, invasion and metastasis. In addition NGAL may also have roles in sequestration of iron resulting in cell survival and tumorigeneis. Upregulated NGAL expression in often upregulated in advanced tumors and is easily detected in urine. Clearly NGAL may represent an important marker for certain cancers.

Recently the role of NGAL in sensitivity to targeted therapy has been investigated in breast cancer cells. Ecotopic expression of NGAL does not increase the resistance of cancer cells to doxorubicin [188]. In contrast, ectopic expression of NGAL did alter the sensitivity of MCF-7 breast cancer cells to targeted therapy [178] MCF-7/NGAL were more sensitive to EGFR, Bcl-2 and calmodulin kinase inhibitors as well as the natural plant product berberine than MCF-7 cells infected with the empty retroviral vector pLXSN. These results are important as the expression of NGAL is often detected at elevated levels after chemotherapy [189]. Furthermore the expression of NGAL increases in more advanced cancers.

\section{SUMMARY}

In this review, we have discussed some of the recent advances in targeting certain signal transduction pathways. Although there have been many advances in our understanding of other key pathways involved in cancer such as Wnt/beta-catenin [190], Notch [191] and hedgehog [192], we have primarily focused on the Ras/ Raf/MEK/ERK and PI3K/PTEN/Akt/mTOR pathways due to space considerations. Clearly as we learn more about these pathways, we find that they have not only complex interactions with other pathways, but the importance of genetics and biochemistry in the sensitivity and resistance to targeted therapy. Further elucidation of these and other signaling pathways may allow more effective therapies to be developed for cancer and other diseases.

\section{ACKNOWLEDGMENTS}

$A B D$ was supported in part by grants from the USAMRMC BC022276, the Intramural RECDA Award and the Italian Association for Cancer Research (AIRC). $\mathrm{MC}$ and GM were supported in part by grants from the Italian 'Ministero dell'Istruzione, dell'Università e della Ricerca (Ministry forEducation, Universities and Research) - MIUR" PRIN 2008 and FIRB-MERIT (RBNE08YYBM). MC was also supported in part by a grant to the CNR from the Italian Ministry of Economy and Finance for the Project FaReBio di Qualità. LC was supported in part by MIUR-PRIN 2009. JDL and PL were supported in part by MNiSzW grants: K/ZDS/001003 and K/PBW/ 000561 from UJCM Krakow, Poland. ML 
was supported in part by a grant from the Italian Ministry of Health, Ricerca Finalizzata Stemness 2008 entitled "Molecular Determinants of Stemness and Mesenchymal Phenotype in Breast Cancer". AMM was supported in part by grants from: MIUR PRIN 2008 (2008THTNLC), and MIUR FIRB 2010 (RBAP10447J-003) and 2011 (RBAP11ZJFA_001). MM was supported in part from the Italian Association for Cancer Research (AIRC), the Cariplo Foundation and the Italian Ministry of Health. AT was supported in part by grants from the Italian "Ministero dell'Istruzione, dell'Università e della Ricerca (Ministry for Education, University and Research) - MIUR - PRIN 2008 and grant from "Sapienza", University of Rome 2009-11.

\section{REFERENCE}

1. McCubrey JA, Steelman LS, Chappell WH, Abrams SL, Montalto G, Cervello M, Nicoletti F, Fagone P, Malaponte G, Mazzarino MC, Candido S, Libra M, Basecke J, Mijatovic S, Maksimovic-Ivanic D, Milella M, et al. Mutations and deregulation of Ras/Raf/MEK/ERK and $\mathrm{PI} 3 \mathrm{~K} / \mathrm{PTEN} / \mathrm{Akt} / \mathrm{mTOR}$ cascades which alter therapy response. Oncotarget. 2012; 3: 954-987.

2. McCubrey JA, Steelman LS, Chappell WH, Abrams SL, Franklin RA, Montalto G, Cervello M, Libra M, Candido S, Malaponte G, Mazzarino MC, Fagone P, Nicoletti F, Basecke J, Mijatovic S, Maksimovic-Ivanic D, et al. Ras/ Raf/MEK/ERK and PI3K/PTEN/Akt/mTOR Cascade Inhibitors: How Mutations Can Result in Therapy Resistance and How to Overcome Resistance. Oncotarget. 2012; 3:1068-1111.

3. Leonardi GC, Candido S, Carbone M, Raiti F, Colaianni V, Garozzo S, Cinà D, McCubrey JA, Libra M. BRAF mutations in papillary thyroid carcinoma and emerging targeted therapies. Mol Med Report. 2012; 6: 687-694.

4. Maira F, Catania A, Candido S, Russo AE, McCubrey JA, Libra M, Malaponte G, Fenga C. Molecular targeted therapy in melanoma: a way to reverse resistance to conventional drugs. Curr Drug Deliv. 2012; 9: 17-29.

5. Steelman LS, Franklin RA, Abrams SL, Chappell W, Kempf CR, Bäsecke J, Stivala F, Donia M, Fagone P, Nicoletti F, Libra M, Ruvolo P, Ruvolo V, Evangelisti C, Martelli AM, McCubrey JA. Roles of the Ras/Raf/MEK/ERK pathway in leukemia therapy. Leukemia. 2011; 25:1080-1094.

6. McCubrey JA, Steelman LS, Kempf CR, Chappell WH, Abrams SL, Stivala F, Malaponte G, Nicoletti F, Libra M, Bäsecke J, Maksimovic-Ivanic D, Mijatovic S, Montalto G, Cervello M, Cocco L, Martelli AM. Therapeutic resistance resulting from mutations in Raf/MEK/ERK and PI3K/ PTEN/Akt/mTOR signaling pathways. J Cell Physiol. 2011; 226: 2762-2781.

7. Steelman LS, Abrams SL, Shelton JG, Chappell WH, Bäsecke J, Stivala F, Donia M, Nicoletti F, Libra M, Martelli AM, McCubrey JA. Dominant roles of the Raf/
MEK/ERK pathway in cell cycle progression, prevention of apoptosis and sensitivity to chemotherapeutic drugs. Cell Cycle. 2010; 9: 1629-1638.

8. Barretina J, Caponigro G, Stransky N, Venkatesan K, Margolin AA, Kim S, Wilson CJ, Lehár J, Kryukov GV, Sonkin D, Reddy A, Liu M, Murray L, Berger MF, Monahan JE, Morais $\mathrm{P}$, et al. The Cancer Cell Line Encyclopedia enables predictive modelling of anticancer drug sensitivity. Nature. 2012; 483: 603-607.

9. Garnett MJ, Edelman EJ, Heidorn SJ, Greenman CD, Dastur A, Lau KW, Greninger P, Thompson IR, Luo X, Soares J, Liu Q, Iorio F, Surdez D, Chen L, Milano RJ, Bignell GR, et al. Systematic identification of genomic markers of drug sensitivity in cancer cells. Nature. 2012; 483: 570-575.

10. Mathieu V, Pirker C, Schmidt WM, Spiegl-Kreinecker S, Lotsch D, Heffeter P, Hegedus B, Grusch M, Kiss R, Berger W. Aggressiveness of human melanoma xenograft models is promoted by aneuploidy-driven gene expression deregulation Oncotarget. 2012; 3: 399-413.

11. Nucera C, Lawler J, Hodin R, Parangi S. The BRAFV600E mutation: what is it really orchestrating in thyroid cancer?. Oncotarget. 2010; 1: 751-756.

12. Kriegl L, Vieth M, Kirchner T, Menssen A. Up-regulation of c-MYC and SIRT1 expression correlates with malignant transformation in the serrated route to colorectal cancer. Oncotarget. 2012; 3: 1182-1193.

13. Pacheco-Pinedo EC, Morrisey EE. Jul. Wnt and Kras signaling-dark siblings in lung cancer. Oncotarget. 2011; 2: 569-574.

14. Shih HJ, Chen HH, Chen YA, Wu MH, Liou GG, Chang WW, Chen L, Wang LH, Hsu HL. Targeting MCT-1 oncogene inhibits Shc pathway and xenograft tumorigenicity. Oncotarget. 2012; 3: 1401-1415.

15. Zhan F, Colla S, Wu X, Chen B, Stewart JP, Kuehl WM, Barlogie B, Shaughnessy JD Jr. CKS1B, overexpressed in aggressive disease, regulates multiple myeloma growth and survival through SKP2- and p27Kip1-dependent and -independent mechanisms. Blood. 2007; 109: 4995-5001.

16. Shi L, Wang S, Zangari M, Xu H, Cao TM, Xu C, Wu Y, Xiao F, Liu Y, Yang Y, Salama M, Li G, Tricot G, Zhan F. Over-expression of CKS1B activates both MEK/ERK and JAK/STAT3 signaling pathways and promotes myeloma cell drug-resistance. Oncotarget. 2010; 1: 22-33.

17. Abrams SL, Steelman LS, Shelton JG, Wong EW, Chappell WH, Bäsecke J, Stivala F, Donia M, Nicoletti F, Libra M, Martelli AM, McCubrey JA. The Raf/MEK/ERK pathway can govern drug resistance, apoptosis and sensitivity to targeted therapy. Cell Cycle. 2010; 9: 1781-1791.

18. Abrams SL, Steelman LS, Shelton JG, Chappell W, Bäsecke J, Stivala F, Donia M, Nicoletti F, Libra M, Martelli AM, McCubrey JA. Enhancing therapeutic efficacy by targeting non-oncogene addicted cells with combinations of signal transduction inhibitors and chemotherapy. Cell Cycle. 2010; 9: 1839-1846. 
19. Chappell WH, Steelman LS, Long JM, Kempf RC, Abrams SL, Franklin RA, Basecke J, Stivala F, Donia M, Fagone P, Malaponte G, Mazzarino MC, Nicoletti F, Libra M, Maksimovic-Ivanic D, Mijatovic S, et al. Ras/Raf/MEK/ ERK and PI3K/PTEN/Akt/mTOR inhibitors: rationale and importance to inhibiting these pathways in human health. Oncotarget. 2011; 2: 135-164.

20. Hou J, Lam F, Proud C, Wang S. Targeting Mnks for cancer therapy. Oncotarget. 2012; 3: 118-131.

21. Corcoran RB, Settleman J, Engelman JA. Potential therapeutic strategies to overcome acquired resistance to BRAF or MEK inhibitors in BRAF mutant cancers. Oncotarget. 2011; 2: 336-346.

22. Koomen JM, Smalley KS. Using quantitative proteomic analysis to understand genotype specific intrinsic drug resistance in melanoma. Oncotarget. 2011; 2: 329-335.

23. Demidenko ZN, McCubrey JA. Recent progress in targeting cancer. Aging. 2011; 3: 1154-1162.

24. Aizman E, Mor A, Levy A, George J, Kloog Y. Ras inhibition by FTS attenuates brain tumor growth in mice by direct antitumor activity and enhanced reactivity of cytotoxic lymphocytes. Oncotarget. 2012; 3: 144-157.

25. Cervello M, McCubrey JA, Cusimano A, Lampiasi N, Azzolina A, Montalto G. Targeted therapy for hepatocellular carcinoma: novel agents on the horizon. Oncotarget. 2012; 3: 236-260.

26. Cervello M, Bachvarov D, Lampiasi N, Cusimano A, Azzolina A, McCubrey JA, Montalto G. Molecular mechanisms of sorafenib action in liver cancer cells. Cell Cycle. 2012; 11: 2843-2855.

27. Singhal R, Kandel ES. The response to PAK1 inhibitor IPA3 distinguishes between cancer cells with mutations in BRAF and Ras Oncotarget. 2012; 3: 700-708.

28. Mashiach-Farkash E, Rak R, Elad-Sfadia G, Haklai R, Carmeli S, Kloog Y, Wolfson HJ, Computer-based identification of a novel LIMK1/2 inhibitor that synergizes with salirasib to destabilize the actin cytoskeleton. Oncotarget. 2012; 3: 629-639.

29. Siu A, Virtanen C, Jongstra J. PIM kinase isoform specific regulation of MIG6 expression and EGFR signaling in prostate cancer cells. Oncotarget. 2011; 2: 1134-1144.

30. Mancias JD, Kimmelman AC. Targeting autophagy addiction in cancer. Oncotarget. 2011; 2: 1302-1306.

31. Ricciardi MR, Scerpa MC, Bergamo P, Ciuffreda L, Petrucci MT, Chiaretti S, Tavolaro S, Mascolo MG, Abrams SL, Steelman LS, Tsao T, Marchetti A, Konopleva M, Del Bufalo D, Cognetti F, Foà R, et al. Therapeutic potential of MEK inhibition in acute myelogenous leukemia: rationale for "vertical" and "lateral" combination strategies. J Mol Med (Berl). 2012; 90: 1133-1144.

32. Lito P, Pratilas CA, Joseph EW, Tadi M, Halilovic E, Zubrowski M, Huang A, Wong WL, Callahan MK, Merghoub T, Wolchok JD, de Stanchina E, Chandarlapaty S, Poulikakos PI, Fagin JA, Rosen N. Relief of Profound
Feedback Inhibition of Mitogenic Signaling by RAF Inhibitors Attenuates Their Activity in BRAFV600E Melanomas. Cancer Cell. 2012; 22: 668-682.

33. Ciuffreda L, Di Sanza C, Cesta Incani U, Eramo A, Desideri M, Biagioni F, Passeri D, Falcone I, Sette G, Bergamo P, Anichini A, Sabapathy K, McCubrey JA, Ricciardi MR, Tafuri A, Blandino G, et al. The mitogen-activated protein kinase (MAPK) cascade controls phosphatase and tensin homolog (PTEN) expression through multiple mechanisms. J Mol Med (Berl). 2012; 90: 667-679.

34. Konopleva M, Milella M, Ruvolo P, Watts JC, Ricciardi MR, Korchin B, McQueen T, Bornmann W, Tsao T, Bergamo P, Mak DH, Chen W, McCubrey J, Tafuri A, Andreeff M. MEK inhibition enhances ABT-737-induced leukemia cell apoptosis via prevention of ERK-activated MCL-1 induction and modulation of MCL-1/BIM complex. Leukemia. 2012; 26: 778-787.

35. Rahmani M, Aust MM, Attkisson E, Williams DC Jr, Ferreira-Gonzalez A, Grant S. Dual inhibition of Bcl-2 and Bcl-xL strikingly enhances PI3K inhibition-induced apoptosis in human myeloid leukemia cells through a GSK3- and Bim-dependent mechanism. Cancer Res. 2012; In Press.

36. Zhang S, Li G, Ma X, Wang Y, Liu G, Feng L, Zhao Y, Zhang G, Wu Y, Ye X, Qin B, Lu J. Norcantharidin enhances ABT-737-induced apoptosis in hepatocellular carcinoma cells by transcriptional repression of Mcl-1. Cell Signal. 2012;9:1803-9

37. Mise J, Dembitz V, Banfic H, Visnjic D. Combined inhibition of PI3K and mTOR exerts synergistic antiproliferative effect, but diminishes differentiative properties of rapamycin in acute myeloid leukemia cells. Pathol Oncol Res. 2011;3:645-56

38. Leontovich AA, Zhang S, Quatraro C, Iankov I, Veroux PF, Gambino MW, Degnim A, McCubrey J, Ingle J, Galanis E, D'Assoro AB. Raf-1 oncogenic signaling is linked to activation of mesenchymal to epithelial transition pathway in metastatic breast cancer cells. Int J Oncol. 2012; 40: 1858-1864.

39. D'Assoro AB, Liu T, Quatraro C, Amato A, Opyrchal M, Leontovich A, Ikeda Y, Ohmine S, Lingle W, Suman V, Ecsedy J, Iankov I, Di Leonardo D, Ayers-Inglers J, Degnim D, Billadeau D, et al Oncogene 2013; In Press.

40. Sander S, Rajewsky K. Burkitt lymphomagenesis linked to MYC plus PI3K in germinal center B cells. Oncotarget. 2012; 3: 1066-1067.

41. Alinari L, Christian B, Baiocchi RA. Novel targeted therapies for mantle cell lymphoma. Oncotarget. 2012; 3: 203-211.

42. Antico Arciuch VG. Russo MA. Dima M. Kang KS. Dasrath F. Liao XH. Refetoff S. Montagna C. Di Cristofano A. Thyrocyte-specific inactivation of p53 and Pten results in anaplastic thyroid carcinomas faithfully recapitulating human tumors. Oncotarget. 2011; 2: 1109-1126. 
43. Weber GL, Parat MO, Binder ZA, Gallia GL, Riggins GJ. Abrogation of PIK3CA or PIK3R1 reduces proliferation, migration, and invasion in glioblastoma multiforme cells. Oncotarget. 2011; 2: 833-849.

44. Dbouk HA, Backer JM. A beta version of life: p110beta takes center stage. Oncotarget. 2010; 1: 729-733.

45. Burger JA, Hoellenriegel J. Phosphoinositide 3'-kinase delta: turning off BCR signaling in Chronic Lymphocytic Leukemia. Oncotarget. 2011; 2: 737-738.

46. Adams JR, Schachter N, Liu JC, Zacksenhaus E, Egan SE. Elevated PI3K signaling drives multiple breast cancer subtypes. Oncotarget. 2011; 2: 435-447.

47. Agoulnik IU, Hodgson MC, Bowden WA. Ittmann MM. INPP4B: the new kid on the PI3K block. Oncotarget. 2011; 2: 321-328.

48. Guirouilh-Barbat JK, Wilhelm T, Lopez BS. AKT1/BRCA1 in the control of homologous recombination and genetic stability: the missing link between hereditary and sporadic breast cancers. Oncotarget. 2010; 1: 691-699.

49. Martelli AM, Chiarini F, Evangelisti C, Grimaldi C, Ognibene A, Manzoli L, Billi AM, McCubrey JA. The phosphatidylinositol 3-kinase/AKT/mammalian target of rapamycin signaling network and the control of normal myelopoiesis. Histol Histopathol. 2010; 25: 669-680.

50. Martelli AM, Evangelisti C, Chiarini F, Grimaldi C, Cappellini A, Ognibene A, McCubrey JA. The emerging role of the phosphatidylinositol 3-kinase/Akt/mammalian target of rapamycin signaling network in normal myelopoiesis and leukemogenesis. Biochim Biophys Acta. 2010; 1803: 991-1002.

51. Martelli AM, Evangelisti C, Chiarini F, McCubrey JA. The phosphatidylinositol 3-kinase/Akt/mTOR signaling network as a therapeutic target in acute myelogenous leukemia patients. Oncotarget. 2010; 1: 89-103.

52. Sokolosky ML, Stadelman KM, Chappell WH, Abrams SL, Martelli AM, Stivala F, Libra M, Nicoletti F, Drobot LB, Franklin RA, Steelman LS, McCubrey JA. Involvement of Akt-1 and mTOR in sensitivity of breast cancer to targeted therapy. Oncotarget. 2011; 2: 538-550.

53. Taylor JR, Lehmann BD, Chappell WH, Abrams SL, Steelman LS, McCubrey JA. Cooperative effects of Akt1 and Raf-1 on the induction of cellular senescence in doxorubicin or tamoxifen treated breast cancer cells. Oncotarget. 2011; 2: 610-626.

54. Hafsi S, Pezzino FM, Candido S, Ligresti G, Spandidos DA, Soua Z, McCubrey JA, Travali S, Libra M. Gene alterations in the PI3K/PTEN/AKT pathway as a mechanism of drugresistance Int J Oncol. 2012; 40: 639-644.

55. Steelman LS, Navolanic P, Chappell WH, Abrams SL, Wong EW, Martelli AM, Cocco L, Stivala F, Libra M, Nicoletti F, Drobot LB, Franklin RA, McCubrey JA. Involvement of Akt and mTOR in chemotherapeutic- and hormonal-based drug resistance and response to radiation in breast cancer cells. Cell Cycle. 2011; 10: 3003-3015.
56. Martelli AM, Evangelisti C, Chappell W, Abrams SL, Bäsecke J, Stivala F, Donia M, Fagone P, Nicoletti F, Libra M, Ruvolo V, Ruvolo P, Kempf CR, Steelman LS, McCubrey JA. Targeting the translational apparatus to improve leukemia therapy: roles of the PI3K/PTEN/Akt/ mTOR pathway. Leukemia. 2011; 25:1064-1079.

57. Steelman LS, Chappell WH, Abrams SL, Kempf RC, Long J, Laidler P, Mijatovic S, Maksimovic-Ivanic D, Stivala F, Mazzarino MC, Donia M, Fagone P, Malaponte G, Nicoletti F, Libra M, Milella M, et al. Roles of the Raf/MEK/ERK and PI3K/PTEN/Akt/mTOR pathways in controlling growth and sensitivity to therapy-implications for cancer and aging. Aging. 2011; 3:192-222.

58. Hart JR. Vogt PK. Phosphorylation of AKT: a mutational analysis. Oncotarget. 2011; 2:467-476.

59. Zawel L. P3Kalpha: a driver of tumor metastasis?. Oncotarget. 2010; 1: 315-316.

60. Schmidt-Kittler O, Zhu J, Yang J, Liu G, Hendricks W, Lengauer C, Gabelli SB, Kinzler KW, Vogelstein B, Huso DL, Zhou S. PI3Kalpha inhibitors that inhibit metastasis. Oncotarget. 2010; 1: 339-348.

61. Garrett JT, Chakrabarty A, Arteaga CL. Will PI3K pathway inhibitors be effective as single agents in patients with cancer?. Oncotarget. 2011; 2: 1314-1321.

62. Sacco A, Roccaro A. Ghobrial IM. Role of dual PI3/Akt and mTOR inhibition in Waldenstrom's Macroglobulinemia. Oncotarget. 2010; 1: 578-582.

63. Chiarini F, Evangelisti C, Buontempo F, Bressanin D, Fini M, Cocco L, Cappellini A, McCubrey JA, Martelli AM. Dual Inhibition of phosphatidylinositol 3-kinase and mammalian target of rapamycin: a therapeutic strategy for acute leukemias. Curr Cancer Drug Targets. 2012; In Press.

64. Chiarini F, Grimaldi C, Ricci F, Tazzari PL, Evangelisti C, Ognibene A, Battistelli M, Falcieri E, Melchionda F, Pession A, Pagliaro P, McCubrey JA, Martelli AM. Activity of the novel dual phosphatidylinositol 3-kinase/mammalian target of rapamycin inhibitor NVP-BEZ235 against T-cell acute lymphoblastic leukemia. Cancer Res. 2010; 70: 80978107.

65. Venkannagari S, Fiskus W, Peth K, Atadja P, Hidalgo M, Maitra A, Bhalla KN. Superior efficacy of co-treatment with dual PI3K/mTOR inhibitor NVP-BEZ235 and panhistone deacetylase inhibitor against human pancreatic cancer. Oncotarget. 2012; 3: 1416-1427.

66. Simioni C, Neri LM, Tabellini G, Ricci F, Bressanin D, Chiarini F, Evangelisti C, Cani A, Tazzari PL, Melchionda F, Pagliaro P, Pession A, McCubrey JA, Capitani S, Martelli AM. Cytotoxic activity of the novel Akt inhibitor, MK2206, in T-cell acute lymphoblastic leukemia. Leukemia. 2012; 26: 2336-2342.

67. Rosner M, Hengstschlager M. mTOR protein localization is cell cycle-regulated. Cell Cycle. 2011; 10: 3608-3610.

68. Jiang Y. mTOR goes to the nucleus. Cell Cycle. 2010; 9: 868. 
69 Huang Y. Ratovitski EA. Phospho-[Greek capital Delta] Np63alpha/Rpn13-dependent regulation of LKB1 degradation modulates autophagy in cancer cells. Aging. 2010; 2: 959-968.

70. Panieri E, Toietta G, Mele M, Labate V, Ranieri SC, Fusco S, Tesori V, Antonini A, Maulucci G, De Spirito M, Galeotti T, Pani G. Nutrient withdrawal rescues growth factor-deprived cells from mTOR-dependent damage. Aging. 2010; 2: 487-503.

71. Lisse TS, Hewison M. Vitamin D: a new player in the world of mTOR signaling. Cell Cycle. 2011; 10: 1888-1889.

72. Blagosklonny MV. Calorie restriction: decelerating mTORdriven aging from cells to organisms (including humans). Cell Cycle. 2010; 9: 683-638.

73. Rodriguez A. Catalan V. Gomez-Ambrosi J. Fruhbeck G. Aquaglyceroporins serve as metabolic gateways in adiposity and insulin resistance control. Cell Cycle. 2011; 10: $1548-1556$.

74. Habib SL. Tuberin and mTOR, a key apoptotic pathway in diabetes. Cell Cycle. 2011; 10: 2237-2238.

75. Blagosklonny MV. Once again on rapamycin-induced insulin resistance and longevity: despite of or owing to. Aging. 2012; 4: 350-358.

76. Zeng LH, McDaniel S, Rensing NR, Wong M. Regulation of cell death and epileptogenesis by the mammalian target of rapamycin (mTOR): a double-edged sword? Cell Cycle. 2010; 9: 2281-2285.

77. D'Arcangelo G. Rapamycin treatment suppresses epileptogenic activity in conditional Pten knockout mice. Cell Cycle. 2010; 9: 2487-2488.

78. Conn CS, Qian SB. mTOR signaling in protein homeostasis: less is more?. Cell Cycle. 2011; 10: 19401947.

79. Tsang CK, Liu H, Zheng XF. mTOR binds to the promoters of RNA polymerase I- and III-transcribed genes. Cell Cycle. 2010; 9: 953-957.

80. Kantidakis T, White RJ. A feedback loop between mTOR and tRNA expression?. Cell Cycle. 2010; 9: 2934-2935.

81. Dalvai M, Schubart K, Besson A, Matthias P. Oct1 is required for $\mathrm{mTOR}$-induced $\mathrm{G} 1$ cell cycle arrest via the control of p27(Kip1) expression. Cell Cycle. 2010; 9: 39333944.

82. Salmond RJ, Zamoyska R. How does the mammalian target of rapamycin (mTOR) influence CD8 T cell differentiation? Cell Cycle. 2010; 9: 2952-2957.

83. Rao RR, Li Q, Shrikant PA. Fine-tuning CD8(+) T cell functional responses: $\mathrm{mTOR}$ acts as a rheostat for regulating CD8(+) T cell proliferation, survival and differentiation? Cell Cycle. 2010; 9: 2996-3001.

84. Woods TC. Regulation of cell migration by mTOR is mediated through changes in p27Kip1 phosphorylation. Cell Cycle. 2010; 9: 2057-2058.

85. Godlewski J, Bronisz A, Nowicki MO, Chiocca EA, Lawler S. microRNA-451: A conditional switch controlling glioma cell proliferation and migration. Cell Cycle. 2010; 9: 2742-2748.

86. Adhikari D, Liu K. mTOR signaling in the control of activation of primordial follicles. Cell Cycle. 2010; 9: 16731674.

87. Rodriguez-Jimenez FJ, Moreno-Manzano V, MateosGregorio P, Royo I, Erceg S, Murguia JR, Sanchez-Puelles JM. FM19G11: A new modulator of HIF that links mTOR activation with the DNA damage checkpoint pathways. Cell Cycle. 2010; 9: 2803-2813.

88. Halicka HD, Zhao H, Li J, Traganos F, Zhang S, Lee M, Darzynkiewicz Z. Genome protective effect of metformin as revealed by reduced level of constitutive DNA damage signaling. Aging. 2011; 3:1028-1038.

89. Leontieva OV, Blagosklonny MV. DNA damaging agents and p53 do not cause senescence in quiescent cells, while consecutive re-activation of mTOR is associated with conversion to senescence. Aging. 2010; 2: 924-935.

90. Serrano M. Shifting senescence into quiescence by turning up p53. Cell Cycle. 2010; 9: 4256-4257.

91. Romanov VS, Abramova MV, Svetlikova SB, Bykova TV, Zubova SG, Aksenov ND, Fornace AJ Jr, Pospelova TV, Pospelov VA. p21(Wafl) is required for cellular senescence but not for cell cycle arrest induced by the HDAC inhibitor sodium butyrate. Cell Cycle. 2010; 9: 3945-3955.

92. Dulic V. Be quiet and you'll keep young: does mTOR underlie p53 action in protecting against senescence by favoring quiescence? Aging. 2011; 3: 3-4.

93. Wang C, Maddick M, Miwa S, Jurk D, Czapiewski R, Saretzki G, Langie SA, Godschalk RW, Cameron K, von Zglinicki T. Adult-onset, short-term dietary restriction reduces cell senescence in mice. Aging. 2010; 2: 555-566.

94. Darzynkiewicz Z. Another "Janus paradox" of p53: induction of cell senescence versus quiescence. Aging. 2010; 2: 329-330.

95. Schug TT. mTOR favors senescence over quiescence in p53-arrested cells. Aging. 2010; 2: 327-328.

96. Martins I, Galluzzi L, Kroemer G. Hormesis, cell death and aging. Aging. 2011; 3: 821-828.

97. Galluzzi L, Kepp O, Kroemer G. Aging. TP53 and MTOR crosstalk to regulate cellular senescence. 2010; 2: 535-537.

98. Iglesias-Bartolome R, Gutkind SJ. Exploiting the mTOR paradox for disease prevention. Oncotarget. 2012; 3: 10611063.

99. Chao SK, Horwitz SB, McDaid HM. Insights into 4E-BP1 and $\mathrm{p} 53$ mediated regulation of accelerated cell senescence. Oncotarget. 2011; 2: 89-98.

100. Fabrizio P, Wei M. Conserved role of medium acidification in chronological senescence of yeast and mammalian cells. Aging. 2011; 3: 1127-1129.

101. Leontieva O, Blagosklonny MV. Yeast-like chronological senescence in mammalian cells: phenomenon, mechanism and pharmacological suppression. Aging. 2011; 3: 1078- 
1091.

102. Blagosklonny MV. Cell cycle arrest is not senescence. Aging. 2011; 3: 94-101.

103. Dulic V. Be quiet and you'll keep young: does mTOR underlie p53 action in protecting against senescence by favoring quiescence?. Aging. 2011; 3: 3-4.

104. Lane DP, Verma C, Fang CC. The p53 inducing drug dosage may determine quiescence or senescence. Aging. 2010; 2: 748 .

105. Wang C, Maddick M, Miwa S, Jurk D, Czapiewski R, Saretzki G, Langie SA, Godschalk RW, Cameron K, von Zglinicki T. Adult-onset, short-term dietary restriction reduces cell senescence in mice. Aging. 2010; 2: 555-566.

106. Korotchkina LG, Leontieva OV, Bukreeva EI, Demidenko ZN, Gudkov AV, Blagosklonny MV. The choice between p53-induced senescence and quiescence is determined in part by the mTOR pathway. Aging. 2010; 2: 393-414.

107. Maki CG. Decision-making by p53 and mTOR. Aging. 2010; 2: 324-326.

108. Menendez JA, Cufi S, Oliveras-Ferraros C, Vellon L, Joven J, Vazquez-Martin A. Aging. 2011; 3: 348-362.

109. Zhao C, Vollrath D. mTOR pathway activation in agerelated retinal disease. Aging. 2011; 3: 346-347.

110. Williamson DL. Normalizing a hyperactive mTOR initiates muscle growth during obesity. Aging. 2011; 3: 83-84.

111. Kofman AE, McGraw MR, Payne CJ. Rapamycin increases oxidative stress response gene expression in adult stem cells. Aging. 2012; 4: 279-289.

112. Sahin M. Eph receptor and mTOR pathway crosstalk: implications for cancer. Cell Cycle. 2010; 9: 2053-2054.

113. Gruppuso PA, Boylan JM, Sanders JA. The physiology and pathophysiology of rapamycin resistance: implications for cancer. Cell Cycle. 2011; 10: 1050-1058.

114. Blagosklonny MV. Why the disposable soma theory cannot explain why women live longer and why we age. Aging. 2010; 2: 884-887.

115. Wesierska-Gadek J. mTOR and its link to the picture of Dorian Gray - re-activation of mTOR promotes aging. Aging. 2010; 2: 892-893.

116. Zhao C, Vollrath D. mTOR pathway activation in agerelated retinal disease. Aging. 2011; 3: 346-347.

117. Passos JF, Zglinicki Tv. Mitochondrial dysfunction and cell senescence--skin deep into mammalian aging. Aging. 2012; 4: 74-75.

118. Blagosklonny MV. Why men age faster but reproduce longer than women: mTOR and evolutionary perspectives. Aging. 2010; 2: 265-273.

119. Blagosklonny MV. Why human lifespan is rapidly increasing: solving "longevity riddle" with "revealed-slowaging" hypothesis. Aging. 2010; 2: 177-182.

120. Blagosklonny MV. Rapamycin and quasi-programmed aging: four years later. Cell Cycle. 2010; 9: 1859-1862.
121. Blagosklonny MV. Increasing healthy lifespan by suppressing aging in our lifetime: preliminary proposal. Cell Cycle. 2010; 9: 4788-4794.

122. Pani G. From growing to secreting: new roles for $m T O R$ in aging cells. Cell Cycle. 2011; 10: 2450-2453.

123. Vigneron A. Vousden KH. p53, ROS and senescence in the control of aging. Aging. 2010; 2: 471-474.

124. Pani G. P66SHC and ageing: ROS and TOR?. Aging. 2010; 2: $514-518$.

125. Goldberg AA, Kyryakov P, Bourque SD, Titorenko VI. Xenohormetic, hormetic and cytostatic selective forces driving longevity at the ecosystemic level. Aging. 2010;2: 461-470.

126. Goldberg AA, Richard VR, Kyryakov P, Bourque SD, Beach A, Burstein MT, Glebov A, Koupaki O, Boukh-Viner T, Gregg C, Juneau M, English AM, Thomas DY. Titorenko VI. Chemical genetic screen identifies lithocholic acid as an anti-aging compound that extends yeast chronological life span in a TOR-independent manner, by modulating housekeeping longevity assurance processes. Aging. 2010; 2: 393-414.

127. Blagosklonny MV. Tumor suppression by p53 without apoptosis and senescence: conundrum or rapalog-like gerosuppression?. Aging. 2012; 4: 450-455.

128. Komarova EA, Antoch MP, Novototskaya LR, Chernova OB, Paszkiewicz G, Leontieva OV, Blagosklonny MV, Gudkov AV. Rapamycin extends lifespan and delays tumorigenesis in heterozygous p53+/- mice. Aging. 2012; 4: 709-714.

129. Comas M, Toshkov I, Kuropatwinski KK, Chernova OB, Polinsky A, Blagosklonny MV, Gudkov AV, Antoch MP. New nanoformulation of rapamycin Rapatar extends lifespan in homozygous p53-/- mice by delaying carcinogenesis. Aging. 2012; 4: 715-722.

130. Blagosklonny MV. Cell cycle arrest is not yet senescence, which is not just cell cycle arrest: terminology for TORdriven aging. Aging. 2012; 4: 159-165.

131. Driscoll MK, Albanese JL, Xiong ZM, Mailman M, Losert W, Cao K. Automated image analysis of nuclear shape: what can we learn from a prematurely aged cell?. Aging. 2012; 4: 119-132.

132. Blagosklonny MV. Molecular damage in cancer: an argument for mTOR-driven aging. Aging. 2011; 3: 1130 1141.

133. Blagosklonny MV. Progeria, rapamycin and normal aging: recent breakthrough. Aging. 2011; 3: 685-691.

134. Blagosklonny MV. Hormesis does not make sense except in the light of TOR-driven aging. Aging. 2011; 3: 1051-1062.

135. Shang YC, Chong ZZ, Wang S, Maiese K. Prevention of beta-amyloid degeneration of microglia by erythropoietin depends on Wnt1, the PI 3-K/mTOR pathway, Bad, and Bcl-xL Aging. 2012; 4: 187-201.

136. Santini E, Valjent E, Fisone G. mTORC1 signaling in Parkinson's disease and L-DOPA-induced dyskinesia: A 
sensitized matter. Cell Cycle. 2010; 9: 2713-2718.

137. Levine AJ. Harris CR. Puzio-Kuter AM. The Interfaces Between Signal Transduction Pathways: IGF-1/mTor, p53 and the Parkinson Disease Pathway. Oncotarget. 2012; 3: 1301-1307.

138. Rambold AS, Lippincott-Schwartz J. Starved cells use mitochondria for autophagosome biogenesis. Cell Cycle. 2010; 9: 3633-3634.

139. Wu JJ, Quijano C, Wang J, Finkel T. Metabolism meets autophagy. Cell Cycle. 2010; 9: 4780-4781.

140. Ciavarra G, Zacksenhaus E. Multiple pathways counteract cell death induced by RB1 loss: implications for cancer. Cell Cycle. 2011; 10: 1533-1539.

141. Castello-Cros R, Bonuccelli G, Molchansky A, Capozza F, Witkiewicz AK, Birbe RC, Howell A, Pestell RG, Whitaker-Menezes D, Sotgia F, Lisanti MP. Matrix remodeling stimulates stromal autophagy, "fueling" cancer cell mitochondrial metabolism and metastasis. Cell Cycle. 2011; 10: 2021-2034.

142. Martinez-Outschoorn UE, Pavlides S, Whitaker-Menezes D, Daumer KM, Milliman JN. Chiavarina B, Migneco G, Witkiewicz AK, Martinez-Cantarin MP, Flomenberg N, Howell A, Pestell RG, Lisanti MP, Sotgia F. Tumor cells induce the cancer associated fibroblast phenotype via caveolin-1 degradation: implications for breast cancer and DCIS therapy with autophagy inhibitors. Cell Cycle. 2010; 9: 2423-2433.

143. Iozzo RV. Autophagic tumor stroma: a biofuel for cancer growth. Cell Cycle. 2011; 10: 3231-3232.

144. Richardson AD, Scott DA. Reversing the Warburg effect through stromal autophagy. Cell Cycle. 2011; 10: 28302831.

145. Korkaya H, Wicha MS. Inflammation and autophagy conspire to promote tumor growth. Cell Cycle. 2011; 10: 2623-2624.

146. Martinez-Outschoorn UE, Whitaker-Menezes D, Pavlides S, Chiavarina B, Bonuccelli G, Casey T, Tsirigos A, Migneco G, Witkiewicz A, Balliet R, Mercier I, Wang C, Flomenberg N, Howell A, Lin Z, Caro J, et al. The autophagic tumor stroma model of cancer or "batteryoperated tumor growth": A simple solution to the autophagy paradox. Cell Cycle. 2010; 9: 4297-4306.

147. Pavlides S, Tsirigos A, Migneco G, Whitaker-Menezes D, Chiavarina B, Flomenberg N, Frank PG, Casimiro MC, Wang C, Pestell RG, Martinez-Outschoorn UE, Howell A, Sotgia F, Lisanti MP. The autophagic tumor stroma model of cancer: Role of oxidative stress and ketone production in fueling tumor cell metabolism. Cell Cycle. 2010; 9: 34853505 .

148. Chiavarina B, Whitaker-Menezes D, Migneco G, MartinezOutschoorn UE, Pavlides S, Howell A, Tanowitz HB, Casimiro MC, Wang C, Pestell RG, Grieshaber P, Caro J, Sotgia F, Lisanti MP. HIF1-alpha functions as a tumor promoter in cancer associated fibroblasts, and as a tumor suppressor in breast cancer cells: Autophagy drives compartment-specific oncogenesis. Cell Cycle. 2010; 9: 3534-3551.

149. Martinez-Outschoorn UE, Trimmer C, Lin Z, WhitakerMenezes D, Chiavarina B, Zhou J, Wang C, Pavlides S, Martinez-Cantarin MP, Capozza F, Witkiewicz AK, Flomenberg N, Howell A, Pestell RG, Caro J, Lisanti MP, et al. Autophagy in cancer associated fibroblasts promotes tumor cell survival: Role of hypoxia, HIF1 induction and NFkappaB activation in the tumor stromal microenvironment. Cell Cycle. 2010; 9: 3515-3533.

150. Bonuccelli G, Tsirigos A, Whitaker-Menezes D, Pavlides S, Pestell RG, Chiavarina B, Frank PG, Flomenberg N, Howell A, Martinez-Outschoorn UE, Sotgia F, Lisanti MP. Ketones and lactate "fuel" tumor growth and metastasis: Evidence that epithelial cancer cells use oxidative mitochondrial metabolism. Cell Cycle. 2010; 9: 3506-3514.

151. Puissant A, Robert G, Auberger P. Targeting autophagy to fight hematopoietic malignancies. Cell Cycle. 2010; 9: 3470-3478.

152. Watson AS, Mortensen M, Simon AK. Autophagy in the pathogenesis of myelodysplastic syndrome and acute myeloid leukemia. Cell Cycle. 2011; 10: 1719-1725.

153. Cluzeau T, Robert G, Puissant A, Jean-Michel K, Cassuto JP, Raynaud S, Auberger P. Azacitidine-resistant SKM1 myeloid cells are defective for AZA-induced mitochondrial apoptosis and autophagy. Cell Cycle. 2011; 10: 2339-2343.

154. Boehrer S, Lainey E, Kroemer G. Coordinated epigenetic regulation of autophagy and apoptosis. Cell Cycle. 2011; 10: $2832-2833$.

155. Shen S, Kepp O, Martins I, Vitale I, Souquere S, Castedo M, Pierron G, Kroemer G. Defective autophagy associated with LC3 puncta in epothilone-resistant cancer cells. Cell Cycle. 2010; 9: 377-383.

156. Galluzzi L, Morselli E, Kepp O, Maiuri MC, Kroemer G. Defective autophagy control by the p53 rheostat in cancer. Cell Cycle. 2010; 9: 250-255.

157. Donia M, McCubrey JA, Bendtzen K, Nicoletti F. Potential use of rapamycin in HIV infection. Br J Clin Pharmacol. 2010; 70: 784-793.

158. Nicoletti F, Fagone P, Meroni P, McCubrey J, Bendtzen K. mTOR as a multifunctional therapeutic target in HIV infection. Drug Discov Today. 2011; 16: 715-721.

159. Altman JK, Sassano A, Platanias LC. Targeting mTOR for the treatment of AML. New agents and new directions. Oncotarget. 2011; 2: 510-517.

160. Evangelisti C, Ricci F, Tazzari P, Tabellini G, Battistelli M, Falcieri E, Chiarini F, Bortul R, Melchionda F, Pagliaro P, Pession A, McCubrey JA, Martelli AM. Targeted inhibition of $\mathrm{mTORC} 1$ and $\mathrm{mTORC} 2$ by active-site $\mathrm{mTOR}$ inhibitors has cytotoxic effects in T-cell acute lymphoblastic leukemia. Leukemia. 2011; 25: 781-791.

161. Buontempo F, Chiarini F, Bressanin D, Tabellini G, Melchionda F, Pession A, Fini M, Neri LM, McCubrey JA, 
Martelli AM. Activity of the selective I $\mathrm{B}$ kinase inhibitor BMS-345541 against T-cell acute lymphoblastic leukemia: involvement of FOXO3a. Cell Cycle. 2012; 11: 2467-2475.

162. Lampiasi N, Azzolina A, D’Alessandro N, Umezawa K, McCubrey JA, Montalto G, Cervello M. Antitumor effects of dehydroxymethylepoxyquinomicin, a novel nuclear factor-kappaB inhibitor, in human liver cancer cells are mediated through a reactive oxygen species-dependent mechanism. Mol Pharmacol. 2009; 76: 290-300.

163. Cervello M, Bachvarov D, Cusimano A, Sardina F, Azzolina A, Lampiasi N, Giannitrapani L, McCubrey JA, Montalto G. COX-2-dependent and COX-2-independent mode of action of celecoxib in human liver cancer cells. OMICS. 2011; 15: 383-392.

164. Cusimano A, Azzolina A, Iovanna JL, Bachvarov D, McCubrey JA, D’Alessandro N, Montalto G, Cervello M. Novel combination of celecoxib and proteasome inhibitor MG132 provides synergistic antiproliferative and proapoptotic effects in human liver tumor cells. Cell Cycle. 2010; 9: 1399-1410.

165. Lampiasi N, Azzolina A, Umezawa K, Montalto G, McCubrey JA, Cervello M. The novel NF-kappaB inhibitor DHMEQ synergizes with celecoxib to exert antitumor effects on human liver cancer cells by a ROS-dependent mechanism. Cancer Lett. 2012; 322: 35-44.

166. Aziz SA, Jilaveanu LB, Zito C, Camp RL, Rimm DL, Conrad P, Kluger HM. Vertical targeting of the phosphatidylinositol-3 kinase pathway as a strategy for treating melanoma. Clin Cancer Res. 2010; 16: 6029-6039.

167. Martelli AM, Chiarini F, Evangelisti C, Cappellini A, Buontempo F, Bressanin D, Fini M, McCubrey JA. Two hits are better than one: targeting both phosphatidylinositol 3-kinase and mammalian target of rapamycin as a therapeutic strategy for acute leukemia treatment. Oncotarget. 2012; 3: 371-394.

168. Bressanin D, Evangelisti C, Ricci F, Tabellini G, Chiarini F, Tazzari PL, Melchionda F, Buontempo F, Pagliaro P, Pession A, McCubrey JA, Martelli AM. Harnessing the $\mathrm{PI} 3 \mathrm{~K} / \mathrm{Akt} / \mathrm{mTOR}$ pathway in T-cell acute lymphoblastic leukemia: eliminating activity by targeting at different levels. Oncotarget. 2012; 3: 811-823.

169. Chiarini F, Lonetti A, Teti G, Orsini E, Bressanin D, Cappellini A, Ricci F, Tazzari PL, Ognibene A, Falconi M, Pagliaro P, Iacobucci I, Martinelli G, Amadori S, McCubrey JA, Martelli AM. A combination of temsirolimus, an allosteric mTOR inhibitor, with clofarabine as a new therapeutic option for patients with acute myeloid leukemia. Oncotarget. 2012; 3: In press.

170. Martelli AM, Chiarini F, Evangelisti C, Ognibene A, Bressanin D, Billi AM, Manzoli L, Cappellini A, McCubrey JA. Targeting the liver kinase B1/AMP-activated protein kinase pathway as a therapeutic strategy for hematological malignancies. Expert Opin Ther Targets. 2012; 16: 729742.

171. Del Barco S, Vazquez-Martin A, Cufi S, Oliveras-Ferraros
C, Bosch-Barrera J, Joven J, Martin-Castillo B, Menendez JA. Metformin: multi-faceted protection against cancer. Oncotarget. 2011; 2: 896-917.

172. Cufi S. Vazquez-Martin A, Oliveras-Ferraros C, MartinCastillo B, Joven J, Menendez JA. Metformin against TGFbeta-induced epithelial-to-mesenchymal transition (EMT): from cancer stem cells to aging-associated fibrosis. Cell Cycle. 2010; 9: 4461-4468.

173. Vazquez-Martin A, Oliveras-Ferraros C, Cufi S, Del Barco S, Martin-Castillo B, Menendez JA. Metformin regulates breast cancer stem cell ontogeny by transcriptional regulation of the epithelial-mesenchymal transition (EMT) status. Cell Cycle. 2010; 9: 3807-3814.

174. Cufi S. Corominas-Faja B. Vazquez-Martin A. OliverasFerraros C. Dorca J. Bosch-Barrera J. Martin-Castillo B. Menendez JA. Metformin-induced preferential killing of breast cancer initiating CD44+CD24-/low cells is sufficient to overcome primary resistance to trastuzumab in HER2+ human breast cancer xenografts. Oncotarget. 2012; 3: 395 398.

175. Grimaldi C, Chiarini F, Tabellini G, Ricci F, Tazzari PL, Battistelli M, Falcieri E, Bortul R, Melchionda F, Iacobucci I, Pagliaro P, Martinelli G, Pession A, Barata JT, McCubrey JA, Martelli AM. AMP-dependent kinase/mammalian target of rapamycin complex 1 signaling in T-cell acute lymphoblastic leukemia: therapeutic implications. Leukemia. 2012; 26: 91-100.

176. Vakana E. Platanias LC. Vakana E. Platanias LC. AMPK in BCR-ABL expressing leukemias. Regulatory effects and therapeutic implications. Oncotarget. 2011; 2: 1322-1328.

177. Habib SL. Mechanism of activation of AMPK and upregulation of OGG1 by rapamycin in cancer cells. Oncotarget. 2011; 2: 958-9.

178. Chappell WH, Abrams SL, Franklin RA, Lahair MM, Montalto G, Cervello M, Martelli AM, Nicoletti F, Candido S, Libra M, Polesel J, Talamini R, Milella M, Tafuri A, Steelman LS, McCubrey JA. Ectopic NGAL expression can alter sensitivity of breast cancer cells to EGFR, Bcl-2, $\mathrm{CaM}-\mathrm{K}$ inhibitors and the plant natural product berberine. Cell Cycle. 2012; 11: 4447-4461.

179. Chappell WH, Lehmann BD, Terrian DM, Abrams SL, Steelman LS, McCubrey JA. p53 expression controls prostate cancer sensitivity to chemotherapy and the MDM2 inhibitor Nutlin-3. Cell Cycle. 2012; 11: 4579-4588.

180. Apontes P, Leontieva OV, Demidenko ZN, Li F, Blagosklonny MV. Exploring long-term protection of normal human fibroblasts and epithelial cells from chemotherapy in cell culture. Oncotarget. 2011; 2: 222233.

181. Steelman LS, Martelli AM, Nicoletti F, McCubrey JA. Exploiting p53 status to enhance effectiveness of chemotherapy by lowering associated toxicity.Oncotarget. 2011; 2: 109-112.

182. Dulińska-Litewka J, McCubrey JA, Laidler P. Increased 
AKT signaling resulting from the loss of androgen responsiveness in prostate cancer. Curr Med Chem. 2013; 20: 144-157.

183. Mijatovic S, Maksimovic-Ivanic D, Timotijevic G, Miljkovic D, Donia M, Libra M, Coco M, McCubrey J, AlAbed Y, Korac A, Stosic-Grujicic S, Nicoletti F. Induction of caspase-independent apoptotic-like cell death of mouse mammary tumor TA3Ha cells in vitro and reduction of their lethality in vivo by the novel chemotherapeutic agent GIT27NO. Free Radic Biol Med. 2010; 48: 1090-1099.

184. Mojic M, Mijatovic S, Maksimovic-Ivanic D, Dinic S, Grdovic N, Miljkovic D, Stosic-Grujicic S, Tumino S, Fagone P, Mangano K, Zocca MB, Al-Abed Y, McCubrey JA, Nicoletti F. Saquinavir-NO-targeted S6 protein mediates sensitivity of androgen-dependent prostate cancer cells to TRAIL. Cell Cycle. 2012; 11: 1174-1182.

185. Donia M, Maksimovic-Ivanic D, Mijatovic S, Mojic M, Miljkovic D, Timotijevic G, Fagone P, Caponnetto S, AlAbed Y, McCubrey J, Stosic-Grujicic S, Nicoletti F. In vitro and in vivo anticancer action of Saquinavir-NO, a novel nitric oxide-derivative of the protease inhibitor saquinavir, on hormone resistant prostate cancer cells. Cell Cycle. 2011; 10: 492-499.

186. Mojic M, Mijatovic S, Maksimovic-Ivanic D, Miljkovic D, Stosic-Grujicic S, Stankovic M, Mangano K, Travali S, Donia M, Fagone P, Zocca MB, Al-Abed Y, McCubrey JA, Nicoletti F. Therapeutic potential of nitric oxide-modified drugs in colon cancer cells.Mol Pharmacol. 2012; 82:700710.

187. Rodvold JJ, Mahadevan NR, Zanetti M. Lipocalin 2 in cancer: when good immunity goes bad. Cancer Lett. 2012; 316: $132-138$.

188. Chappell WH, Abrams SL, Montalto G, Cervello M, Martelli AM, Candido S, Libra M, Polesel J, Talamini R, Arlinghaus R, Steelman LS, McCubrey JA. Effects of ectopic expression of NGAL on doxorubicin sensitivity. Oncotarget. 2012; 3: 1236-1245.

189. Chappell WH, Abrams SL, Stadelman KM, Lahair MM, Franklin RA, Cocco L, Evangelisti C, Chiarini F, Martelli AM, Steelman LS, McCubrey JA. Increased NGAL (Lnc2) expression after chemotherapeutic drug treatment. Adv Biol Regul. 2012 Sep 16. doi:pii: S2212-4926(12)00088-7. 10.1016/j.jbior.2012.09.004).

190. Curtin JC. Lorenzi MV. Drug discovery approaches to target Wnt signaling in cancer stem cells. Oncotarget. 2010; 1: 563-577.

191. Piazzi G. Fini L. Selgrad M. Garcia M. Daoud Y. Wex T. Malfertheiner P. Gasbarrini A. Romano M. Meyer RL. Genta RM. Fox JG. Boland CR. Bazzoli F. Ricciardiello L. Epigenetic regulation of Delta-Like1 controls Notch1 activation in gastric cancer. Oncotarget. 2011; 2: 12911301.

192. Mazumdar T. DeVecchio J. Agyeman A. Shi T. Houghton JA. The GLI genes as the molecular switch in disrupting Hedgehog signaling in colon cancer. Oncotarget. 2011; 2: 